\title{
The Metaphor of Cultural Entanglement in Northeast African Archaeology
}

\author{
Julia Budka* \\ Professor of Egyptian Archaeology, LMU Munich, Germany
}

Submission: April 23, 2018; Published: May 04, 2018

*Corresponding author: Julia Budka, Principal investigator of ERC Across Borders Project, Professor of Egyptian Archaeology, LMU Munich, Institute of Egyptology, Katharina-von-Bora-Str. 10, D-80333 München, Germany, Tel: +49 (0) 89/289 27543, Email: Julia.Budka@lmu.de

Keywords: Archaeology; Metaphor; Ancient Egypt; Centric Bias; Egyptian; Nubia; Egyptianization; Colonialism; Cultural Entanglement; Kerma Culture; Autochthony; Allochthony; Biological Entanglement; Stockhammer; Austrian Science; Northern Sudan; Indigenous Cultures

\section{Introduction}

Archaeology in Northeast Africa has long been dominated by ancient Egypt and its rich cultural heritage. The monuments located in modern Sudan, ancient Nubia, were first described and analyzed by Egyptologists and traditionally viewed from an "Egyptian" perspective [1], resulting in several shortcomings in assessing African indigenous cultures. Many studies exhibit an Egypt centric bias and are referring primarily to written Egyptian sources which have been read as accurate evidence, partly neglecting archaeological findings [2].

In particular during the Second Millennium BCE, during the periods of the Egyptian Middle Kingdom and New Kingdom, Egypt "colonialized" parts of northern Sudan - Egyptian fortresses, temples and towns were built, an Egyptian administration was installed. The corresponding archaeological remains attest not only to an Egyptian presence but also to certain adaptations of the Egyptian culture. The latter was labelled as "Egyptianization" and described as one of the main features of Egyptian colonialism in Nubia. However, in recent years, fresh theoretical approaches have stimulated a diverse discussion and moved away from this too simplistic point of view of processes which were in reality very complex and exhibit local features [3]. New work in Egypt and Sudan has begun to identify impenetrable boundaries and prominent ethnic categorization in Second Millennium BCEas modern conceptions that are no longer supportable [4-6]. Since 2013 , the concept of "cultural entanglement" is also discussed for New Kingdom Nubia [7]. The direct impact of these new approaches on archaeological fieldwork in Northern Sudan was investigated within the European Research Council across Borders project, taking the island of Sai in northern Sudan where Egyptian culture met with the Nubian Kerma culture as a case study.

\section{New Approaches to Egyptian and Nubian Archaeology}

One of the buzzwords in recent archaeological studies dealing with settlement remains in Northern Sudan is "entanglement". For about five years now, the well-established concept of "Egyptianization" has been subject to criticism on the grounds that it projects a one-dimensional and static view of culture. In its stead, a model based on the notion of "cultural entanglement" has been suggested $[7,8]$, borrowing from a more advanced discussion in Mediterranean archaeology and also studies about Romanization [9]. Ongoing excavation work on New Kingdom sites in Sudan has since expanded the material basis of the debate and has shown how central the dynamics of cultural intermingling really are [10-13].

Similar to research in North America and elsewhere, the use of "entanglement" in Sudanese archaeology is related to colonial and postcolonial studies $[14,15]$. What has yet not been touched in detail is the question, whether entanglement in Northeast African archaeology is used as a model or as a metaphor [14]. Its relation to the older idea of "Egyptianization" might suggest that it is regarded as a model. Similar to the concept of hybridity [8], which has been discussed in a number of recent papers on Nubian New Kingdom sites and is especially well traceable in pottery vessels, this could cause several problems. It seems therefore more reasonable to use "entanglement" as metaphor [14]. I would argue that "cultural entanglement" stands for an important redirection of the archaeological interpretation of finds in Northern Sudan, but should not be regarded as the one and only solution. Following Stockhammer's (2012, 49-51) categories, small finds, ceramics and other objects can be seen as evidence of "material entanglement". 
Biologic entanglement is another theme recently discussed in Northeast African archaeology [6]. Especially the funerary evidence suggests that the individuals buried at the New Kingdom sites in northern Sudan were both Egyptians and Nubians and therefore represent a complex community. Related to this new theory, the systematic variation in the isotopic composition of Strontium in the environment and in dental enamel of ancient skeletons was analyzed in the last decade for tracing human migration in Nubian archaeology. The isotope signals can be used as basis for the further interpretation of the autochthony or allochthony of the skeletal remains of the excavated individuals. Ongoing analyses, for example from the Across Borders project, will provide relevant new data in the near future. Again, I would argue that "biological entanglement" is first of all a metaphor to mark the redirection of an interpretation, away from strict categories like "Nubians" and "Egyptians".

\section{Sai Island as a Case Study}

One of the most promising examples of a "colonial site" built during the New Kingdom in northern Sudan is the town on Sai Island because of its long occupation period and its attested history during the African Kingdom of Kerma. Prior to the New Kingdom, Sai was the northernmost stronghold of the Kerma Kingdom with a significant strategic role, well attested by archaeological remains. As is the case with other Egyptian colonial sites, the archaeological evidence of Sai strongly hints at it originally being an Egyptian foundation. However, similar to other sites, indigenous Nubian elements are also present and from the beginning of the Across Borders project, which has investigated Sai Island between 2012 and 2018, it was clear that these African features have to be carefully assessed for the period of the New Kingdom. In order to achieve a better understanding of the situation on Sai, a bottom-up approach to the investigation of the society in the New Kingdom town was introduced, also taking into account new data from the contemporaneous elite cemetery on the island.

Across Borders' multi-faceted research suggests that at the local level social, economic and cultural identities were changing, interacting and merging with each other. Sai can, therefore, be regarded as an example for the dynamic and situational character of past societies [16] for which firm categories like "Nubians", Egyptians" and "Egyptianized Nubians" fall short.

\section{Outlook}

From my perspective, there has been a major development in Egypt and Nubian archaeology in the last decade and here in particular in the study of New Kingdom Nubia. Important advances were made regarding the concept of "Egyptianization" which is now replaced by approaches using theories of cultural entanglement and appropriation [7]. The notion of the importance of indigenous people for the area and the period was also high lightened [17] - other than drawing artificial border lines between Egyptians and Nubians, the focus should be on interacting identities of people. The Across Borders project and its interpretation of Sai exhibit this new methodological development and its advances. With a fresh emphasis on the importance of the micro histories and individuals of specific sites, the "entanglement" approach developed in the last years for Nubia can also be of relevance for sites located in Egypt [18-19]. I am confident that this new metaphor describing complex interAfrican intermingling of cultures will result in fresh insights in Northeast African Archaeology in the upcoming decade.

\section{Acknowledgement}

This paper is an outcome of the author's European Research Council Starting Grant project no. 313668 and could built on results from her Austrian Science Fund FWF START project Y615-G19.

\section{References}

1. Edwards DN (2004) The Nubian Past. Archaeology of Sudan, Routledge, London and New York, USA.

2. Liszka $\mathrm{K}$ (2011) We have come from the well of Ibhet: ethnogenesis of the Medjay. Journal of Egyptian History 4 (2): 149-171.

3. De Souza AM (2013) The Egyptianisation of the Pan-Grave Culture: a new look at an old idea. The Bulletin of the Australian Centre for Egyptology 24: 109-126.

4. Smith ST (2003) Wretched Kush. Ethnic identities and boundaries in Egypt's Nubian Empire. Routledge, London and New York.

5. Smith ST, Buzon M (2014) Colonial entanglements: Egyptianization in Egypt's Nubian Empire and the Nubian Dynasty. In: Anderson JR, Welsby DA (Eds.), The Fourth Cataract and Beyond. Proceedings of the $12^{\text {th }}$ International Conference for Nubian Studies, British Museum Publications on Egypt and Sudan 1: 431-442.

6. Smith ST, Buzon M (2017) Colonial encounters at New Kingdom Tombos: Cultural entanglements and hybrid identity. In: Spencer N, Stevens A, Binder M (Eds.), Nubia in the New Kingdom. Lived Experience, Pharaonic Control and Indigenous Traditions. British Museum Publications on Egypt and Sudan 3: 615-630.

7. Van Pelt WP (2013) Revising Egypto-Nubian Relations in New Kingdom Lower Nubia: From Egyptianization to Cultural Entanglement. Cambridge Archaeological Journal 23(3): 523-550.

8. Stockhammer PW (2012) Conceptualizing cultural hybridization in archaeology, In: Stockhammer PW (Eds.), Conceptualizing Cultural Hybridization. A Trans disciplinary Approach, Springer, Berlin and Heidelberg: 43-58.

9. Stockhammer PW (2013) From Hybridity to Entanglement, from Essentialism to Practice. Archaeological Review from Cambridge Issue 28(1): 11-28.

10. Spencer N (2014) Creating and re-shaping Egypt in Kush: Responses at Amara West. Journal of Ancient Egyptian Inter connections 6(1): 42-61.

11. Budka J (2015) The Pharaonic town on Sai Island and its role in the urban landscape of New Kingdom Kush. Sudan \& Nubia 19: 40-53.

12. Budka J (2017) The $18^{\text {th }}$ Dynasty on Sai Island - new data from excavations in the town area and cemetery SAC5. Sudan and Nubia 21: 71-81.

13. Spencer N, Stevens A, Binder M (2017) Introduction: History and historiography of a colonial entanglement, and the shaping of new archaeologies for Nubia in the New Kingdom. In: Spencer N, Stevens A, Binder M (Eds.), Nubia in the New Kingdom. Lived Experience, Pharaonic Control and Indigenous Traditions. British Museum Publications on Egypt and Sudan 3, Peeters, Leuven: 1-61. 
14. Silliman SW (2016) Disentangling the Archaeology of Colonialism and Indigeneity. In: Der L, Fernandini F (Eds.), Archaeology of Entanglement, Left Coast Press Walnut Creek, CA p. 31-48.

15. Hodder I (2012) Entangled. An Archaeology of the Relationships between Human and Things, Wiley-Blackwell, Malden, MA and Oxford.

16. Budka J (2017b) Across Borders In: The New Kingdom Town of Sai Island, Sector SAV1 North. Contributions to the Archaeology of Egypt, Nubia and the Levant 4, Austrian Academy of Sciences Press, Vienna.

This work is licensed under Creative Commons Attribution 4.0 License

DOI: 10.19080/GJAA.2018.03.555621
17. Morkot R (2013) From conquered to conqueror: the organization of Nubia in the New Kingdom and the Kushite administration of Egypt. In: Moreno García JC (Eds.), The Administration of Egypt. Handbuch der Orientalistik 104: 911-963.

18. Bader B (2013) Cultural Mixing in Egyptian Archaeology: The 'Hyksos' as a Case Study. Archaeological Review from Cambridge Issue 28(1): 257-286.

19. Bietak M (2016) The Egyptian Community at Avaris during the Hyksos Period. Egypt and the Levant 26: 263-274.

\section{Your next submission with Juniper Publishers will reach you the below assets}

- Quality Editorial service

- Swift Peer Review

- Reprints availability

- E-prints Service

- Manuscript Podcast for convenient understanding

- Global attainment for your research

- Manuscript accessibility in different formats

(Pdf, E-pub, Full Text, Audio)

- Unceasing customer service

Track the below URL for one-step submission https://juniperpublishers.com/online-submission.php 